\begin{tabular}{ll}
\hline \hline MINING AND METALLURGY INSTITUTE BOR & ISSN: 2334-8836 (Štampano izdanje) \\
UDK: 622 & ISSN: 2406-1395 (Online) \\
\hline \hline
\end{tabular}

\title{
OPTIONS OF IMPLEMENTATION THE MODERN BUSINESS QUALITY MANAGEMENT METHODS IN MINING
}

\begin{abstract}
Modern business conditions, which are reflected in the process of the world market globalization, inevitably influence all spheres of business. With the aim of continued existence, the growth and development, companies in all sectors are required to follow the modern tendencies in business processes. Mining, as a base business operation, with all its specificities is not excluded from this process. Furthermore, the modern technological processes are based on scientific research in all segments of business, as well as on implementation the innovative scientific accomplishments in all areas of scientific activity. This paper is based on consideration the economic aspect of application the modern business methods, through implementation of methods for the business process improvement regarding to the mining complex, in actual work on presenting the effects of innovative procedures in the lead-zinc ore flotation in the 'Kopaonik' - RMHK 'Trepca' facility.

Keywords: innovation, production, management, reengineering, system performance
\end{abstract}

\section{INTRODUCTION}

The modern world, economic environment and companies themselves undergo the constant changes. Restructuring, reorganization and other great changes are necessary frequently, with the aim of improving the company, or at least, ensuring its survival in increasingly harsher market competition. The mining complex, as a very intricate system, is not spared from these influences. If anything, it is even more affected by the technical - technological innovative changes. Keeping in mind that an 'economic - value indicator of mining reserves and mining production indicate that lead reserves on the territory of Serbia amount to $6 \%$ of the world reserves, or $20 \%$ of the European reserves and zinc reserves are $4 \%$ of the world and $14 \%$ of the European reserves ${ }^{1}$, focus on exploitation of this potential through implementation the modern economic - technological methods is the im perative of the modern mining production. Adapting companies to modern business conditions is a prerequisite for implementation a growth and development strategy, as well as recovery and survival, with serious implications to the national economic activity. This conclusion is derived from the fact that the 'foreign trade, enabled by mining operations production, was of strategic importance for national economy of Serbia. Non-ferrous and precious metals, non-ferrous metals concentrates and products held the top positions in export. ${ }^{2}$ Precisely, due to this reason, the managers and experts have been dealing with problems related to a transformation as a special phenomenon since the nineteen-nineties of the twentieth century until today, although the various enterprise restructuring models existed before that time. In this sense, the organizational - technolo-

\footnotetext{
* Faculty of Technical Sciences - Kosovska Mitrovica

** Faculty of Economics - Kosovska Mitrovica

**** Flotation facility "Kopaonik" Leposavić - RMHK "Trepča”
} 
gical changes are among the most delicate, considering they affect the entire company, so the role of these changes in the overall company performance is particularly emphasized. The effective ness of these changes can be viewed in the context of effect the organizational changes on various aspects of business, primarily on the business efficiency in terms of cost reduction and management's reaction in crisis situations and understanding of changes and manner of their influence on workforce performance.

\section{INNOVATIVENESS A AS PRECONDITION FOR HIGHER BUSINESS QUALITY}

Considering the fact that innovation implies a process of introduction the new findings in economy, investments in the new technology and employees are necessary for its realization. This leads to the conclusion that, in order to execute decisions for implementation of innovations, a significant investment of capital is necessary for obtainning the new technology and workforce trainings. Implementation of innovations in the base industry, such as mining, is a precondition for business success of a company. Creative thinking should be an integral part of a long - term capability of a company, which is the foundation of innovation. Analyses show that companies which grow faster are those that implement the new knowledge and innovations. The difference between the successful and less successful ones lies in different approach to innovations.

Companies that wish to keep the existing and win the new markets must innovate more efficiently than their competitors, as well as secure human and material resources for the purpose of innovative activities. The most important thing about innovations and innovators is creating an aspiration for achievement the desired results.

In the modern business context, scientific laws and manners of their practical application are the primary and decisive for successful business dealings of a company. Scientific laws are the basis for development of innovations. All innovations are the result of human creative processes. It would be difficult to find an innovation which is not based on the already known scientific law, more or less modified. Each innovation involves a number of changes which need to be executed in an organization. The modern scientific research has shown that the actual knowledge and skills that people possess and using that knowledge in practice are the principal and decisive condition for development the work productivity. The only successful management systems are those with strong intellectual base.

The latest approaches to innovation supplement the models which see its origins in connecting the technical capabilities with the market needs. Innovative companies serve as a model, influenced by two main groups of environmental factors: current use of products and processes on one hand, and needs, i.e. demand for the new products and processes, on the other.

\section{SELECTION OF METHODS FOR THE BUSINESS QUALITY IMPROVEMENT}

Quality improvement is conditioned by application the adequate methods which are either already known, or the strategic management of a company needs to create them. In that Sense, the management has several, already tested methods on its disposal, such as the following:

- Business Process Reengineering

- Production System Just in time (JIT)

- Balanced Scorecard (BSC)

- Total Productive Maintenance (TPM)

- Total Quality Management (TQM)

- ISO System

- Method Six Sigma

- Lean Manufacturing

- European Foundation for Quality Management (EFQM)

- The Twenty Keys Method

Considering the specific nature of their application in the quality improvement process, each of these methods must be considered separately, so that the company management could decide for the ones that will secure the highest possible level of efficien 
cy the managerial activity. One of potential strategic options involves the processes reengineering, which is the focus of this paper, with consideration of reengineering application in the mining - processing complex, with presentation the actual results of this concept application in the floatation facility “Kopaonik” Leposavic.

\section{AN EXAMPLE OF BUSINESS PROCESS REENGINEERING IN THE FACILITY FOR FLOTATION OF LEAD-ZINC ORE "KOPAONIK" LEPOSAVIC - RMHK "TREPCA"}

In the ever more competitive environment in which the companies operate, there is a requirement for continual development and innovation. One of the possibilities for achieving that is the application of reengineering as a radical approach. Constant changes in the world markets and application the new technologies lead to the new dynamic objectives and strategies and changes at all company levels. One of the management concepts for achieving the new strategy goals is the business process reengineering. Reengineering is a new beginning, i.e. an attempt to do the business differently than before. The reasons which indicate the need for reengineering are the sharp competition, constant changes and more demanding customers.

Practical illustration of reengineering as the company management's strategic option from the perspective of mining - processing industry with all its specificities is shown in an example of operative section of the RMHK Trepca - flotation of lead-zinc ore in the 'Kopaonik' facility, located in Leposavic.

The 'Kopaonik' Leposavic facility is a part of RMHK Trepca - North, and its main operation is related to the processing (flotation) of lead-zinc ore from the capacity of the following mines:

'Belo Brdo', 'Crnac', 'Zuta Prla' and open pit 'Koporic'. The main facility, which is the focus of this paper, possesses 375.000 t of annual capacity. During exploitation, this facility processed approximately 7.5 million tons of lead-zinc ore, out of which $333.000 \mathrm{t}$ was lead concentrate with $70-72 \%$ lead content $(\mathrm{Pb})$ and around $390.000 \mathrm{t}$ of zinc concentrate with $47-49 \%$ content $(\mathrm{ZN})$. The current market flows, technical - technological characteristics of production process, as well as more stable, social and political climate, lead to a management's decision on reengineering the production capacities in terms of improvement the technical - technological features of production facility. The main goal of these measures is to modernize the technological process, which will lead to better use of ore reserves, as well as an increase in processing capacities. Comparative analysis of processing quality of the old and new, technologically more advanced facility, are presented in Tables 1 and 1a.

Table 1 Grain size distribution of KMD 1200T crusher (old crusher)

\begin{tabular}{|c|l|l|l|}
\hline Particle size class, $\mathbf{~ m m}$ & $\mathbf{M} \%$ & $\mathbf{M} \% \downarrow$ & $\mathbf{M} \% \boldsymbol{}$ \\
\hline 20 & 33.3 & 33.3 & 100 \\
\hline-5 & 16.1 & 49.4 & 66.7 \\
\hline-5 & 20.3 & 69.7 & 50.6 \\
\hline$-10+0,3$ & 28 & 97.7 & 30.3 \\
\hline-0.3 & 2.3 & 100 & 2.3 \\
\hline
\end{tabular}

Table 1a Grain size distribution of $\mathrm{CH} 420$ crusher (new crusher)

\begin{tabular}{|c|c|c|c|}
\hline Particle size class, mm & $\mathbf{M \%}$ & $\mathbf{M \%} \downarrow$ & $\mathbf{M \%} \uparrow$ \\
\hline 20 & 4 & 4 & 100 \\
\hline-5 & 11.5 & 15.5 & 96 \\
\hline-5 & 41.5 & 57 & 84.5 \\
\hline$-10+0,3$ & 38.2 & 95.2 & 43 \\
\hline-0.3 & 4.8 & 100 & 4.8 \\
\hline
\end{tabular}


The comparative analysis presented above (Tables 1 and 1a) of grain size distribution of crushed ore clearly indicates the result of tech-innovation, particularly in a size class $-15 \mathrm{~mm}$, where this grain size as a representative sample in KMD-1200 T crusher is present in $50 \%$ of the total amount of processed ore, while with $\mathrm{CH}-420$ crusher that is a technological innovation of the processing method, the content of the same size amounts to $84.5 \%$ of the total amount of processed ore.

Comparative analysis of processing capacity (grinding) indicates that the grinding capacity has been increased from $620 \mathrm{t}$ of processed ore per day to $820 \mathrm{t}$ of processed ore on a daily basis, which in cumulative monthly quantities is an in-crease of around $5.000 \mathrm{t}$ in the amount of processed ore. So, this innovation through reengineering of the production process, in terms of improvement the technological processes, only through capacity increases, leads to an unequivocal conclusion on significance the management innovative actions. The economic effect of implementation the innovative action is also reflected in a considerable reduction in electric energy costs by $30 \%$ (from $110 \mathrm{~kW}$ to $77 \mathrm{~kW}$ ), lower maintenance costs, as well as the use of agents frothers from $50 \mathrm{~g} / \mathrm{t}$ to $25 \mathrm{~g} / \mathrm{t}$, i.e. by $50 \%$. Besides all these advantages, the technological superiority of innovation is particularly important when it comes to the environmental protection and employees' health.

The parameters presented above confirm a justifiability of reengineering implementation as a strategic option of company because, as it can be seen from the afore mentioned parameters, reengineering of technical - technological parameters in terms of adapting the technical - technological processes to the needs of the specific market, leads to a significant improvement in economic business parameters, in this particular case to increase in operational capacity (former bottle neck) by $35 \%$, leading to an increase in mining production, which is a raw material base of flotation. In the final outcome, apart from the cost reduction, this has a significant cumulative effect on improvement the financial parameters of company.

Reengineering process must be comprehensive in order to successfully combine the all specific potentials of company on one hand, and the environment needs, on the other. Reengineering methodology is defined in six phases. Each phase involves a group of processes, comprised of a number of activities. Each process can be expanded or adjusted so as to comply with all individual requirements of company and reengineering as a whole. Each organizational unit of company should be given a separate consideration and for each of them, teams should be formed, consisting of people with adequate level of knowledge, Figure 1.

Reengineering is combination the strategy for enhancing the business innovation and strategy for making improvements in the process. Although potential cost effectiveness of reengineering is great, there is also a risk of failure due to the environmental disturbances. During implementation of reengineering, traps which can emerge and which should be avoided, such as a lack of vision or inefficient reengineering team.

Cost reduction and quality improvement are the main conditions for survival of every production system. Product competitiveness is measured by the quality, price, delivery term and customer's satisfaction, so continual quality improvement contributes to the ability of producer to accomplish them.

'Reengineering implies the fundamental rethinking and radical redesign of business processes - in order to achieve the dramatic improvements in critical, important performance measures, such as the costs, quality, service and speed. ${ }^{3}$ 


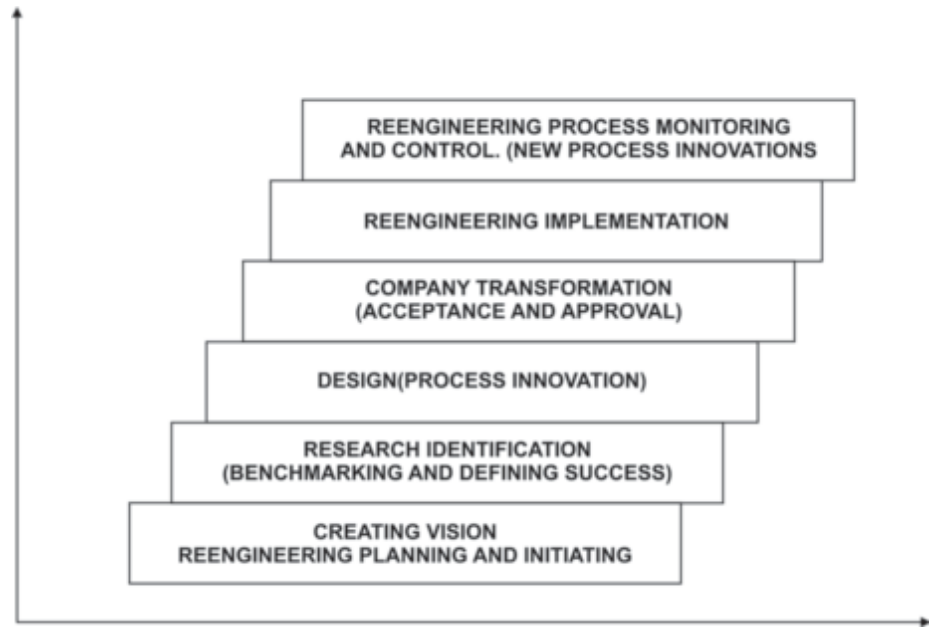

Figure 1 Reengineering methodology presentation

(Source: Miladinović, Ž., Adamović, Ž., Impact of Reengineering on Improving Companies' Business Quality, International Scientific Conference on Management 2010, p. 341)

Even in times of economic crisis, reengineering is interesting because it offers fast and efficient solutions. Modern economic crisis indicates that, apart from efficiency, social criteria must be taken into consideration, as well as interests of employees, customers, public services, etc. Interest in engineering is also present in the financial sector, education system, judiciary system, military and other branches of economy, which, of course, includes mining and ore processing. Reengineering should be additionally enhanced, so that it can achieve the certain new goals which were not that pronounced originally. This primarily involves a new consideration for demand for product quality and need for prompter response to the market demands, both of which require a constant acknowledgement and support of the new knowledge and creativity.

Success of reengineering implementation calls for definition the key processes. Key processes carriers are responsible for the process implementation, monitoring and correction, if necessary. These are, most frequently, leaders, managers, teams and consultants. They are the company members with special knowledge and skills, indivi- duals with authority and experience in implementation of certain changes. Furthermore, they need to be people of trust, with charisma and influence on behavior of their employees, team work oriented and acting within the accepted reengineering concept. Leaders' role in the reengineering process is to create a vision, motivate the employees, define key values and createteams for design and implementation the radical changes.

Apart from the top manager, who initiates the change process, leads and motivates the employees during the transition phase, as potential change management agents, literature mentions the groups or individuals who plan and implement changes, and consultants, comprised of groups of people with a vision of necessary changes, but without authority and control of resources required for initiating the changes. 4

Business processes reengineering is a transition into a new technological model without division of business processes into sectors or functions, but the organization is based on the business processes, the main goal of which is to meet the customers' needs. Reengineering at the process level implies radical changes of certain business 
processes, in the area of material processing or information.

Competition makes impact on the business system with the aim of protection their customers and market position. Systems behave in two manners - some implement reengineering as a preventive measure, which enables them to keep current position or expand within the existing or new markets, while the others act when their market position is threatened, and when advantages of the competitor are visible.

\section{CONCLUSION}

Monitoring and implementation the modern trends in the business process organization, today is the foundation of growth and development the successful company. Monitoring and implementation dynamics should certainly be adjusted to the dynamics of the field in which the business operates, but being in the specific economic branch does not reduce the need for participation in the modern business flows. Business process of reengineering, as one of the strategic options for management action, is one of the most efficient options, especially when it comes to the production industry, and then it involves technical and technological aspect of business.

Mining, being the base industry, is characterized by not so fast technical and technological changes, i.e. environments' demands for change. However, the main motive for innovativeness of the business process arises from the economic parameters which, even with the specificities of the base industry, are observed through the lens of financial results.

Considering the all specificities of mining and ore processing on one hand, and business process requirements, on the other, 'the lowest common denominator' must be found which would drive the overall business towards growth and development. This common denominator are business costs, i.e. inclination towards their reduction because they are the latent basis for business success. Based on that, the business process of reengineering is viewed as a formula of choice when it comes to implement the mentioned inclinations, which can be clearly seen in description and presented results of the representative example of the 'Kopaonik' flotation, stated in this paper. This strategic option certainly requires securing the adequate conditions, technical, as well as financial, and conditions regarding to the human resource. However, it is important to emphasize that reengineering can be successfully applied in the business processes of the base industry, what was the purpose of this paper work.

\section{REFERENCES}

[1] Bahtijarevic - Shiber F.: Managing Organizational Changes, Economic Analyst, 1993.

[2] Vujić S. et al: Mineral Raw Materials Complex of Serbia and Montenegro at the Cross-Road of Two Millenniums, Faculty of Mining and Geology Belgrade, Engineering Academy of Yugoslavia, Association of Mining and Geological Engineers, Belgrade, 2003, p. 632 (in Serbian)

[3] Goodbody Alibhe: Floating on Air, Mining Magazine, November 2011.

[4] Hammer M., Champy J.: Reengineering the Corporation A Manifesto for Business Revolution, 1997.

[5] Miladinović Ž., Adamović Ž., The Impact of Re-engineering to Improve the Quality of Operations in Companies, International Scientific Conference Management, 2010. 